\title{
PENGARUH BURSA SAHAM GLOBAL SYARIAH TERHADAP JAKARTA ISLAMIC INDEX PERIODE TAHUN 2015-2017
}

\section{The Effect of Sharia Global Stock Exchange on Jakarta Islamic Index Period Of 2015-2017}

\author{
Samsul Anwar, Lisa Kustina, Fitri Kaniawati \\ Manajemen FE Unwir, Akuntansi STIE Pelita Bangsa, \\ Akuntansi STIE Pelita Bangsa \\ anwar_909@yahoo.com, Lisakustina188@gmail.com, Fitrikania15@gmail.com
}

\begin{abstract}
ABSTRAK
Penelitian ini bertujuan untuk mengetahui pengaruh bursa saham global syariah yang diwakili oleh variabel Dow Jones Islamic Market Index Europe, Dow Jones Islamic Market Index Malaysia, Dubai Financial Market General Index, Tadawul All Share Index terhadap Jakarta Islamic Index. Penelitian ini menggunakan data sekunder yang berupa data index saham bulanan periode tahun 2015-2017. Analisis data dalam penelitian ini menggunakan analisis deskriptif dan analisis regresi linear. Data diolah dengan menggunakan software eviews. Hasil dari penelitian ini menunjukan bahwa variabel Dow Jones Islamic Market Index Europe secara parsial berpengaruh terhadap Jakarta Islamic Index periode 2015-2017. Sedangkan Dow Jones Islamic Market Index Malaysia, Dubai Financial Market General Index, dan Tadawul All Share Index tidak berpengaruh signifikan terhadap Jakarta Islamic Index periode 2015-2017.
\end{abstract}

Kata kunci: Dow Jones Islamic Market Index Europe, Dow Jones Islamic Market Index Malaysia, Dubai Financial Market General Index, Tadawul All Share Index, Jakarta Islamic Index.

\begin{abstract}
This study aims to determine the effect of the global Islamic stock exchange represented by the variable Dow Jones Islamic Market Index Europe, Malaysia's Dow Jones Islamic Market Index, Dubai Financial Market General Index, the Tadawul All Share Index against the Jakarta Islamic Index. This study uses secondary data in the form of monthly stock index data for the period 2015-2017. Data analysis in this study used descriptive analysis and linear regression analysis. Data is processed using software
\end{abstract}

eviews. The results of this study indicate that the Dow Jones Islamic Market Index Europe variable is partially influential on the Jakarta Islamic Index for the 2015-2017 period. While the Malaysian Dow Jones Islamic Market Index, Dubai Financial Market General Index, and Tadawul All Share Index did not significantly influence the Jakarta Islamic Index for the 2015-2017 period.

Keywords: Europe's Dow Jones Islamic Market Index, Malaysia's Dow Jones Islamic Market Index, Dubai Financial Market General Index, Tadawul All Share Index, Jakarta Islamic Index.

\section{PENDAHULUAN}

Pasar modal memiliki peranan yang sangat penting dalam perekonomian suatu negara. Sebagai negara yang pasar keuangannya sedang berkembang, pasar modal menjadi bagian penting dalam perekonomian Indonesia, karena pasar modal menurut Halim dan Marcories (2011) diartikan sebagai suatu sistem keuangan yang terorganisasi menjadi pasar tempat bertemunya pembeli dan penjual dalam berbagai instrument keuangan jangka panjang, seperti utang jangka panjang dan modal, yang dapat diperjual 
belikan baik dalam bentuk utang, ekuitas (saham), dan instrumen derivative.

Indonesia, negara yang memiliki populasi penduduknya mayoritas beragama islam dan masih dalam usia produktif, pasar modal syariah di Indonesia berpotensi sangat besar dan terus berkembang, karena pasar modal syariah sangatlah penting bagi perekonomian suatu negara itu sendiri, ini berdampak pada pertumbuhan pasar secara rill melalui investasi berbasis syariah, investasi berbasis syariah tersebut terintegrasi dengan nilai-nilai agama yang dianut investor ketika memilih instrumen investasinya (Oktaviani, 2017).

Pasar modal syariah di Indonesia pada mulanya berawal dari keinginan untuk memenuhi kebutuhan umat Islam yang ingin berinvestasi dengan prinsip syariah. Hal inilah yang kemudian melatarbelakangi pendirian perbankan syariah pertama yaitu Bank muamalat pada tahun 1990 disusul dengan Reksa dana syariah pada tahun 1997 dan pasca krisis tahun 1998 dibentuklah saham syariah pertama yaitu Jakata islamic index pada tahun 2000 .
Perkembangan pasar modal syariah di Indonesia tidak lepas dari pengaruh pasar modal global karena saat ini pasar modal syariah sangat berkembang pesat diseluruh penjuru dunia. Penyebaran keuangan syariah menurut Rahmah (2018) terbesar berada di wilayah Middle East and North Africa (MENA) sebesar 38\%, Gulf Cooperation Council (GCC), yaitu Bahrain, Kuwait, Qatar, Oman, United Arab Emirates, dan Arab Saudi sebesar $34 \%$ serta Asia sebesar 23\%. Selain negara-negara yang mayoritas penduduknya beragama islam, keuangan syariah juga menyebar hingga ke negara yang mayoritas penduduknya non islam seperti wilayah Eropa sebesar 4\%. Pasar modal global, ada juga pasar modal Eropa dan Malaysia. Berdasarkan hasil penelitian yang dilakukan oleh Oktaviani (2017) menghasilkan kesimpulan bahwa Dow Jones Islamic Market Index Europe (DJIEU) tidak berpengaruh signifikan terhadap Jakarta Islamic Index (JII) dan Dow Jones Islamic Market Index Malaysia (DJIMY) berpengaruh positif dan signifikan terhadap Jakarta Islamic Index (JII). Selain itu ada juga penelitian dari Solechudin dan Harjito 
Samsul Anwar, Lisa Kustina dan Nila anarih

(2011) yang menyatakan bahwa nilai saham di negara Dubai secara langsung tidak mempengaruhi saham Negara Indonesia.

Fluktuasi pergerakan indeks saham, nilai kapitalisasi serta peristiwa-peristiwa yang dapat memberikan pengaruh bagi Jakarta Islamic Index. Gejolak yang pernah terjadi sepanjang tahun 2011-2016 di Arab Saudi yang memungkinkan dapat mempengaruhi bursa saham global yaitu terjadinya peristiwa Arab Spring, dimulai dengan adanya peristiwa bakar diri Bouazizi pada 17 Desember 2010 yang kemudian tersebar hingga negaranegara Timur Tengah lainnya, menurut Yasmine (2015) Arab Spring menjadi sebuah fenomena yang 'secara paksa' membawa demokrasi ke dunia Arab yang selama berdekade sebelumnya pada umumnya menerapkan sistem autokrasi. Selain itu karena adanya peristiwa Arab Spring hubungan Arab Saudi dan Iran retak, berdampak pada tidak mendapatkannya kerja sama dengan Suriah yang selama ini menjadi wilayah strategis dalam hal perdagangan minyak (Mustahyun, 2017).
Peristiwa Arab Spring yang terjadi di Arab Saudi menyebar sampai ke Dubai dan berdampak pada perekonomian Dubai yang selama ini dikenal sebagai negara yang cukup stabil dan menjadi pusat bisnis global, hasil penelitian dari Alshariri dan Abubaker (2016) menunjukan bahwa politik yang terjadi di wilayah tersebut tidak signifikan mempengaruhi pasar modal Dubai yaitu Dubai Financial Market (DFM), Meskipun tidak signifikan mempengaruhi Dubai Financial Market (DFM) namun mempengaruhi volatilitas dua indeks dari DFM yaitu indeks Transportasi dan Telekomunikasi.

Selain Arab Saudi dan Dubai yang dapat mempengaruhi Jakarta Islamic Index (JII) menarik untuk di cermati dan di uji, sejauh mana pengaruh bursa saham global khususnya syariah yang diwakili oleh Dow Jones Islamic Market Index Europe (DJIEU), Dow Jones Islamic Market Malaysia (DJMY25D), Dubai Financial Market General Index (DFMGI), dan Tadawul All Share Index (TASI) terhadap Jakarta Islamic Index selama kurun waktu 2015-2017. 
Perumusan masalah dalam penelitian ini adalah:

1. Apakah terdapat pengaruh bursa saham global Dow Jones Islamic Market Index Europe (DJIEU) terhadap Jakarta Islamic Index Periode Tahun 2015-2017?

2. Apakah terdapat pengaruh bursa saham global Dow Jones Islamic Market Index Malaysia Titan 25 USD (DJMY25D) terhadap Jakarta Islamic Index Periode Tahun 2015$2017 ?$

3. Apakah terdapat pengaruh bursa saham global Dubai Financial Market General Index (DFMGI) terhadap Jakarta Islamic Index Periode Tahun 2015-2017?

4. Apakah terdapat pengaruh bursa saham global Tadawul All Share Index (TASI) terhadap Jakarta Islamic Index Periode Tahun 20152017 ?

\section{TINJAUAN PUSTAKA}

Jakarta Islamic Index (JII)

Jakarta Islamic Index

merupakan 30 saham syariah terbaik di Bursa Efek Indonesia. Review saham syariah yang menjadi konstituen JII dilakukan sebanyak dua kali dalam setahun, Mei dan November.
Perhitungan saham syariah pada JII dilakukan PT Bursa Efek Indonesia dengan menggunakan metode perhitungan indeks yang ditetapkan dengan bobot kapitalisasi pasar (Market Capitalization Weighted) yang mencakup penyesuaian-penyesuaian yang dilakukan oleh adanya perubahan terhadap emiten yaitu corporate action (Oktaviani, 2017).

Jakarta Islamic Index terus melakukan pertumbuhan yang mengesankan, pada akhir tahun 2017 indeks JII berharga 759,07 dan terus mengalami peningkatan meskipun di tahun 2015 sempat turun di harga 603,35 . Hingga data terkini diambil pada hari Jum'at, 24 Agustus 2018 adalah 646,6 untuk harga penutupan Jakarta Islamic Index

Dow Jones Islamic Market Index

Dow Jones Islamic Market Index (DJIM) diluncurkan pada Februari 1999 di Bahrain dan merupakan indeks Islam pertama di dunia muslim. DJIM diluncurkan sebagai respon dan perwujudan minat kalangan investor muslim yang besar baik di negara Amerika maupun di seluruh dunia. Keberadaan Dow Jones Islamic Market 
Samsul Anwar, Lisa Kustina dan Nila anarih

memberikan dampak bagi perkembangan investasi diberbagai negara, Dow Jones Islamic Market Index ini meliputi saham-saham dari 34 negara, serta mencakup 10 sektor ekonomi, 18 sektor pasar, 51 kelompok industri dan 89 sub kelompok industri (Beik dan Fatmawati, 2014). Beberapa negara yang termasuk ke dalam Dow Jones Islamic Market Index diantaranya Dow Jones Market Index Europe (DJIEU) dan Dow Jones Islamic Market Malaysia (DJMY).

Perkembangan index Dow Jones Islamic Market Index Europe dan Malaysia dari tahun ke tahun cukup fluktutif. Dow Jones Islamic Market Index Europe, pada akhir tahun 2017 indeks DJIEU ini berharga 3703,87 dan terus mengalami peningkatan meskipun di tahun 2016 sempat turun di harga 2948,51. Hingga data terkini diambil pada hari Jum'at, 24 Agustus 2018 adalah 3.693,47 untuk harga penutupan Dow Jones Islamic Market Index Europe. Sedangkan Dow Jones Islamic Market Index Malaysia, pada akhir tahun 2017 indeks DJMY25D berharga 833,70 dan di tahun 2016 sempat turun di harga 687,78. Hingga data terkini diambil pada hari Jum'at,
24 Agustus 2018 adalah 840,24 untuk harga penutupan Dow Jones Islamic Market Index Malaysia.

Dubai Financial Market General Index (DFMGI)

Negara Dubai dikenal sebagai negara dari timur tengah yang memiliki kekuatan baru dalam bisnis global. Namun pada tahun 2009 Dubai menanggung hutang yang besar. Sehingga otoritas Negara Dubai meminta penangguhan pembayaran hutang pokok (standstill) sampai enam bulan kepada para kreditur manca Negara, Hutang Negara Dubai disebabkan oleh pembangunan dalam skala besar untuk membangun sebuah kota bisnis yang diberi nama Dubai World, Sebagai pengelola utama pembangunan Dubai World, konsorsium Dubai World meminta kepada para kreditur untuk menangguhkan penerimaan pembayaran hutang sampai Mei 2010. (Solechudin dan Harjito, 2011).

Krisis Dubai dapat menjadi guncangan bagi pasar keuangan negara lain, kekhawatiran tersebut berdampak pada sulitnya pinjaman bank sehingga dapat memperlambat pemulihan 
ekonomi global. Hal ini ditunjukkan dalam penelitan yang dilakukan oleh pratiwi, et al (2012) yang menyatakan apabila hutang obligasi perusahaan investasi Dubai sebesai US\$ 60 milliar mengalami gagal bayar, maka bankbank internasional akan mengalami kerugian yang besar. Dalam penelitian tersebut juga dikemukakan bahwa harga saham Dubai berpengaruh terhadap Malaysia dan Harga saham Malaysia mempengaruhi negara Thailand dan Singapura. Dubai sebagai negara yang pertama menerapkan konsep syariah secara penuh pada bursa sahamnya

Tadawul All Share Index (TASI)

Tadawul All Share Index (TASI) adalah index saham yang disebarluaskan oleh Pasar modal Saudi Arabia. Penelitian yang dilakukan oleh Cahyadin dan Milandari (2009) mengemukakan bahwa pasar saham syariah Arab Saudi termasuk dalam kategori semi-kuat karena informasi yang membentuk harga saham syariah padasaat ini tidak hanya informasi di masa lalu tetapi juga informasi yang berjalan. Hasil dari penelitian tersebut menunjukan bahwa korelasi antara bursa saham syariah Arab Saudi (TASI) dan Amerika Serikat (IMUS) sangat lemah, sedangkan indeks harga saham syariah Tadawul All Share Index mempengaruhi Jakarta Islamic Index (JII) meskipun bursa saham syariah Arab Saudi tidak terkait secara langsung dengan bursa saham syariah Indonesia dan Amerika Serikat.Hal ini dapat diartikan bahwa hubungan kerjasama yang dapat menguntungkan antara dua negara yaitu Indonesia dan Arab Saudi harus dilakukan.

Hipotesis Penelitian

Dow Jones adalah salah satu indeks pasar saham yang didirikan oleh editor The Wall Street Journal dan pendiri Dow Jones \& Company yaitu Charles Dow. Dow Jones secara resmi dimulai sejak 26 Mei 1896 dan pada bulan Februari 1999 Dow Jones Islamic Market Index (DJIM) diluncurkan di Bahrain. Hasil Penelitian dari Oktaviani (2017) menunjukkan bahwa Indeks Dow Jones Islamic Market Europe tidak berpengaruh signifikan terhadap Jakarta Islamic Index. Dengan 
Samsul Anwar, Lisa Kustina dan Nila anarih

demikian hipotesis yang diajukan adalah:

H1: Dow Jones Islamic Market Index Europe berpengaruh terhadap Jakarta Islamic Index

Pasar modal syariah di Malaysia awal terbentuk dikarenakan permintaan pasar yang begitu besar pada awal tahun 90-an yaitu sejak awal tahun 1990, Bursa Malaysia bergabung dalam konstitues Dow Jones Islamic Index pada tanggal 31 Desember 2012. Hasil Penelitian dari Beik dan Fatmawati (2014) menunjukkan bahwa Indeks Dow Jones Islamic Market Malaysia secara positif dan signifikan mempengaruhi JII. Dengan demikian hipotesis yang diajukan adalah:

H2: Dow Jones Islamic Market Index Malaysia 25 USD berpengaruh terhadap Jakarta Islamic Index

Dubai Financial Market General Index adalah indeks harga pasar modal Dubai, didalamnya terdapat sahamsaham perusahaan yang memiliki kapitalisasi tinggi. Nilai dasar indeks ini adalah 1000 pada 1 Januari 2004. Hasil Penelitian dari Pratiwi, et al (2012) menunjukkan bahwa harga saham Dubai berpengaruh signifikan terhadap harga saham Malaysia.
Dengan demikian hipotesis yang diajukan adalah:

H3: Dubai Financial Market General Index berpengaruh terhadap Jakarta Islamic Index Tadawul All Share Index (TASI) adalah index saham yang disebarluaskan oleh Pasar modal Saudi Arabia. Indeks ini dikembangkan dengan nilai dasar 1000 pada tahun 1985 dan direstrukturisasi pada 30 Juni 2008. Hasil Penelitian dari Cahyadin dan Milandari (2009) menunjukkan bahwa Tadawul All Share Index berpengaruh terhadap Jakarta Islamic Index. Dengan demikian hipotesis yang diajukan adalah:

H4: Tadawul All Share Index berpengaruh terhadap Jakarta Islamic Index

\section{METODOLOGI PENELITIAN}

Jenis penelitian ini adalah jenis penelitian Kuantitatif. Penelitian Kuantitatif adalah jenis penelitian dengan menggunakan data sekunder atau data time series. Data sekunder dalam penelitian ini adalah data yang diperoleh dari hasil Publikasi id.investing.com, yahoo finance dan bloomberg. 
Data yang digunakan adalah data bulanan yang dipublikasikan. Penelitian ini menggunakan tekhnik analisi linear berganda dan diolah dengan menggunakan software eviews.

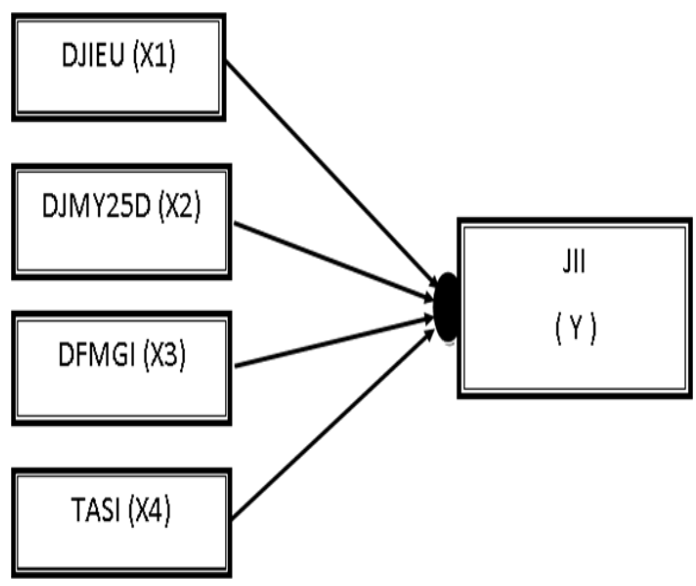

\section{PEMBAHASAN}

Hasil olah data menggunakan eviews adalah sebagai berikut

$$
\text { Hasil Uji Hipotesis }
$$

Dependent Variable: JII

Method: Least Squares

Date: 08/05/18 Time: 14:22

Sample: 2015M01 2017M12

Included observations: 36

\begin{tabular}{crccc}
\hline Variable & Coefficient & Std. Error & t-Statistic & Prob. \\
\hline DJEU & 0.126870 & 0.034398 & 3.688299 & 0.0009 \\
DIMY25D & 0.159205 & 0.161994 & 0.982779 & 0.3333 \\
DFMGI & 0.053977 & 0.051356 & 1.051045 & 0.3014 \\
TASI & -0.029149 & 0.015230 & -1.913914 & 0.0649 \\
C & 176.1680 & 170.0471 & 1.035995 & 0.3082 \\
\hline R-squared & 0.351924 & Mean dependent var & 687.0161 \\
Adjusted R-squared & 0.268302 & S.D. dependent var & 55.96539 \\
S.E. of regression & 47.87245 & Akaike info criterion & 10.70320 \\
Sum squared resid & 71044.91 & Schwarzcriterion & 10.92314 \\
Log likelihood & -187.6577 & Hannan-Quinn criter. & 10.77997 \\
F-statistic & 4.208477 & Durbin-Watson stat & 0.428709 \\
Prob(F-statistic) & 0.007764 & & & \\
\hline
\end{tabular}

Sumber: Data sekunder diolah, 2018

Dari tabel diatas diperoleh nilai thitung untuk masing-masing variabel
DJIEU: 3,688, DJMY25D: 0,983, DFMGI: 1,051 dan TASI: -1,914. Sedangkan nilai ttabel diperoleh dari degree of freedom $(\mathrm{df})=\mathrm{n}-(\mathrm{k}+1)$, dalam hal ini $\mathrm{n}$ adalah jumlah sample, $\mathrm{k}$ adalah jumlah variabel independen. Pada penelitian ini $\mathrm{n}=36, \mathrm{k}=4$ dan besarnya df dapat dihitung 36$(4+1)=31$ dan $\alpha=0,05$ didapat nilai tabel 2,040.

\section{Hasil Uji Hipotesis Satu (H1)}

Uji hipotesis satu digunakan untuk menguji pengaruh bursa saham global syariah Dow Jones Islamic Market Index Europe terhadap Jakarta Islamic Index. Untuk melakukan pengujian hipotesis kesatu, digunakan uji t satu sisi kanan. Dari table diperoleh nilai thitung sebesar 3,688 dengan tanda koefisien positif. Dengan nilai ttabel sebesar 2,040 pada tingkat signifikan $5 \%$.

Dari table dapat dilihat bahwa thitung sebesar 3,688 dan ttabel sebesar 2,040 pada signifikan $5 \%(\sigma=0.05)$. Nilai thitung lebih besar dari ttabel $(3,688>$ 2,040) sehingga dapat disimpulkan bahwa H1 diterima, artinya bursa saham global syariah Dow Jones Islamic Market Index Europe 
Samsul Anwar, Lisa Kustina dan Nila anarih

berpengaruh positif terhadap Jakarta Islamic Index. Hasil penelitian ini serupa dengan penelitian yang dilakukan oleh Beik dan Fatmawati (2014) dengan kesimpulannya yaitu index saham syariah di Indonesia (JII) memiliki hubungan positif dan signifikan dengan indeks saham syariah Eropa (DJIEU).

\section{Hasil Uji Hipotesis Dua (H2)}

Uji hipotesis dua digunakan untuk menguji pengaruh bursa saham global syariah Dow Jones Islamic Market Index Malaysia terhadap Jakarta Islamic Index. Untuk melakukan pengujian hipotesis kedua, digunakan uji t satu sisi kanan. Dari table diperoleh nilai thitung sebesar 0,983 dengan tanda koefisien positif. Dengan nilai ttabel sebesar 2,040 pada tingkat signifikan 5\%.

Dari table dapat dilihat bahwa thitung sebesar 0,983 dan ttabel sebesar 2,040 pada signifikan $5 \%(\sigma=0.05)$. Nilai thitung lebih kecil dari ttabel $(0,983 \leq 2,040)$ sehingga dapat disimpulkan bahwa $\mathrm{H} 2$ ditolak, artinya bursa saham global syariah Dow Jones Islamic Market Index Malaysia tidak berpengaruh terhadap Jakarta Islamic Index. Hasil penelitian ini serupa dengan penelitian yang dilakukan oleh Ardana (2017) dengan kesimpulannya yaitu index saham syariah di Indonesia (JII) tidak dipengaruhi oleh indeks saham syariah Malaysia (DJIMY) dan indeks saham syariah Malaysia (DJIMY) tidak menciptakan contagion effect saat terjadi guncangan krisis Yunani.

3. Hasil Uji Hipotesis Tiga (H3)

Uji hipotesis tiga digunakan untuk menguji pengaruh bursa saham global syariah Dubai Financial Market General Index terhadap Jakarta Islamic Index. Untuk melakukan pengujian hipotesis ketiga, digunakan uji t satu sisi kanan. Dari table diperoleh nilai thitung sebesar 1,051 dengan tanda koefisien positif. Dengan nilai t-tabel sebesar 2,040 pada tingkat signifikan $5 \%$.

Dari table dapat dilihat bahwa thitung sebesar 1,051 dan ttabel sebesar 2,040 pada signifikan 5\% $(\sigma=0.05)$. Nilai thitung lebih kecil dari ttabel $(1,051 \leq 2,040) \quad$ sehingga dapat disimpulkan bahwa H3 ditolak, artinya bursa saham global syariah Dubai Financial Market General Index tidak berpengaruh terhadap Jakarta Islamic Index. Hasil penelitian ini serupa 
dengan penelitian yang dilakukan oleh Solechudin dan Harjito (2011), penelitian tersebut menghasilkan kesimpulan yaitu harga saham Dubai tidak berpengaruh positif terhadap Indonesia.

\section{Hasil Uji Hipotesis Empat (H4)}

Uji hipotesis empat digunakan untuk menguji pengaruh bursa saham global syariah Tadawul All Share Index terhadap Jakarta Islamic Index. Untuk melakukan pengujian hipotesis keempat, digunakan uji t satu sisikanan. Dari table diperoleh nilai thitung sebesar -1,914 dengan tanda koefisien negatif. Dengan nilai t-tabel sebesar 2,040 pada tingkat signifikan 5\%.

Dari table dapat dilihat bahwa thitung sebesar -1,914 dan ttabel sebesar 2,040 pada signifikan 5\% ( $\sigma=$ 0.05 ). Nilai thitung lebih kecil dari ttabel $(-1,914 \leq 2,040)$ sehingga dapat disimpulkan bahwa H4 ditolak, artinya bursa saham global syariah Tadawul All Share Index tidak berpengaruh terhadap Jakarta Islamic Index.

Hasil penelitian ini bertolak belakang dengan penelitian yang dilakukan oleh Cahyadin dan Milandari (2009) menunjukkan bahwa Tadawul
All Share Index berpengaruh terhadap Jakarta Islamic Index.

Hasil Uji Determinasi

Koefisien determinasi (R2) pada dasarnya mengukur seberapa jauh kemampuan model dalam menerangkan variasi variable dependen. Nilai koefisien determinasi adalah antara 0-1. Nilai R2 yang berarti kemampuan variable-variable independen dalam menjelaskan variasi variable dependen amat terbatas. Hasil uji determinasi dapat dilihat pada table sebagai berikut:

Tabel 5.8

Hasil Uji Determinasi

\begin{tabular}{lrll}
\hline \hline R-squared & 0.351924 & Mean dependent var & 687.0161 \\
Adjusted R-squared & 0.268302 & S.D. dependent var & 55.96539 \\
S.E. of regression & 47.87245 & Akaike info criterion & 10.70320 \\
Sutm squafed resid. & 71044.91 & Schwarz criterion & 10.92314 \\
Log likelihood & -187.6577 & Hannan-Quinn criter. & 10.77997 \\
F-statistic & 4.208477 & Durbin-Whateon stat & 0.428709 \\
Prob(F-statistic) & 0.007764 & & \\
\hline
\end{tabular}

Sumber: Data Sekunder Olah, 2018

Berdasarkan table diatas, menunjukkan bahwa besarnya nilai koefisien determinasi atau $\mathrm{R}$ Square adalah 0,352 atau 35,2\%. Angka ini menunjukkan bahwa 35,2\% variabel JII mampu dijelaskan oleh variabel DJIEU, DJMY25D, DFMGI dan TASI. Sedangkan sisanya $64,8 \%$ dijelaskan 
Samsul Anwar, Lisa Kustina dan Nila anarih

oleh variabel lain diluar model yang terdapat dalam penelitian ini. Untuk koefisien determinasi yang disesuaikan (R2 adjusted) menunjukan angka 0.268, yang berarti bahwa setelah mempertimbangkan derajat kebebasan model yang digunakan, seluruh variabel indepeden yang digunakan dalam penelitian ini menjelaskan Jakarta Islamic Index (JII) sebesar $26.8 \%$.

\section{KESIMPULAN}

Variabel bursa saham global syariah Dow Jones Islamic Market Index Europe (DJIEU) berpengaruh positif terhadap Jakarta Islamic Index pada periode tahun 2015-2017. Adanya pengaruh tersebut dikarenakan pasar kuat mempengaruhi pasar yang lebih lemah, dimana perekonomian di Negara maju akan berpengaruh terhadap perekonomian dinegara berkembang yang ditunjukan dari indeks bursa sahamnya.

Variabel bursa saham global syariah Dow Jones Islamic Market Index Malaysia (DJMY25D) tidak berpengaruh terhadap Jakarta Islamic Index pada periode tahun 2015-2017. Tidak adanya pengaruh ini dikarenakan Dow Jones Islamic Market Index Malaysia (DJMY25D) terkena dampak issue politik yaitu pemilihan presiden yang membuat perekonomian Malaysia mengalami penurunan dilihat dari modal dan investor asing yang keluar dari saham Malaysia dengan arus yang keluar lebih dari $\$ 224,4$ juta. Serta utang publik sebagai presentase Produk Domestic Bruto (PDB) tercatat sebesar $80,3 \%$.

Variabel bursa saham global syariah Dubai Financial Market General Index (DFMGI) tidak berpengaruh terhadap Jakarta Islamic Index pada periode tahun 2015-2017. Tidak adanya pengaruh ini kemungkinan karena adanya gejolak Arab Spring yang berdampak pada Bursa Saham Dubai dimana pada saat itu Arab Spring mempengaruhi dua index saham Dubai Financial Market yaitu Transportasi dan Telekomunikasi. Variabel bursa saham global syariah Tadawul All Share Index (TASI) tidak berpengaruh terhadap Jakarta Islamic Index pada periode tahun 2015-2017. 
Tidak adanya pengaruh ini kemungkinan karena adanya gejolak Arab Spring yang terjadi sepanjang tahun 2011-2016 dimana hubungan Arab Saudi dan Iran retak, berdampak pada Arab Saudi yang tidak mendapatkan posisi kerjasama dengan Suriah dalam hal perdagangan minyak yang mampu menambah penghasilan negara karena wilayah Suriah sangat strategis.

\section{DAFTAR PUSTAKA}

Irfan Syauqi Beik, Sri Wulan Fatmawati, 2014, Pengaruh Indeks Harga Saham Syariah Internasional Dan Variabel Makro Ekonomi Terhadap Jakarta Islamic Index, Jurnal AlIqtishad: Vol. Vi No. 2, Juli 2014. Johan Halim \& Marcories, 2011, Analisis Pengaruh Pergerakan Bursa Internasional Terhadap Pergerakan Bursa Indonesia, Journal Of Applied Finance And Accounting 3(2) 181-203.

Malek Alsharairi \& Wa'el Abubaker, 2016, Does Arab Spring Have A Spillover Effect on Dubai
Financial Market? The Journal of Developing Areas, Tennessee State University, USA, 2016.

Malik Cahyadin \& Devi Oktaviana Milandari, 2009, Analisis Efficient Market Hypothesis (EMH) Di Bursa Saham Syariah, 2005:1 - 2008:11, La_Riba Jurnal Ekonomi Islam, Vol. III, No. 2, Desember 2009.

Monica Weni Pratiwi, Anang Sucahyo, dan Solechhudin, 2012, Pendekatan Contagion theory terhadap krisis dubai, Jurnal Manajemen Magister, Vol 03. No.02, Juli 2017.

Mustahyun, 2017, Rivalitas Arab Saudi Dan Iran Di Timur Tengah pada Arab Spring Tahun 2011-2016, Islamic World and Politics Vol.1 No.1 Juli-Desember 2017 ISSN:2614-0535.

Retno Fuji Oktaviani, 2017, Index Harga Saham Islamic Internasional terhadap Jakarta Islamic Index, Jurnal Ekonomika dan Manajemen Vol. 6 No. 1 April 2017 ISSN: 2252-6226.

Shafira Elnanda Yasmine, 2015, Arab Spring: Islam dalam gerakan sosial dan demokrasi Timur 
Samsul Anwar, Lisa Kustina dan Nila anarih

Tengah, Masyarakat,

Kebudayaan dan Politik Vol. 28,

No. 2, tahun 2015, hal. 106-113.

Solechuddin, D. Agus Harjito, 2011,

Efek Kontagion Krisis Dubai

Terhadap Return Saham Di

Negara-Negara Asia Tenggara,

Jurnal Ekobis Vol.12, No.1,

Januari 2011.

www.bloomberg.com

www.finance.yahoo.com

www.idx.com

www.investing.com

www.ojk.com 